\title{
Sugar, Starch, and Proline in Peach Trees Exposed to Freezing Temperatures during Dehardening
}

\author{
Seok Kyu Yun1, Haejin Bae ${ }^{2 *}$, Kyung-Ho Chung1, Ik Koo Yoon1, Eun Young Nam1, \\ Jung Hyun Kwon', Ji Hae Jun1 \\ ${ }^{1}$ Fruit Research Division, National Institute of Horticultural and Herbal Science, Rural Development \\ Administration, Suwon, Korea \\ ${ }^{2}$ National Institute of Ecology, Fruit Research Division, National Institute of Horticultural and Herbal Science, \\ Suwon, Korea \\ Email: ${ }^{*}$ sky0611@korea.kr
}

Received 10 June 2014; revised 24 July 2014; accepted 21 August 2014

Copyright (C) 2014 by authors and Scientific Research Publishing Inc.

This work is licensed under the Creative Commons Attribution International License (CC BY). http://creativecommons.org/licenses/by/4.0/

(c) (i) Open Access

\section{Abstract}

Freezing temperatures cause different levels of freezing injury and change biochemical components of trees. In this study, the range of survival temperature and variation in electrolyte leakage, and in concentrations of sugar, starch, and proline were determined in peach twigs (Jinmi, Changhowonhwangdo, and Kawanakajima Hakuto) exposed to artificially controlled freezing temperature. Freezing temperatures at which the plants were damaged by stress were found to be $-21^{\circ} \mathrm{C}$ in Jan. and Feb., $-18^{\circ} \mathrm{C}$ in Mar., and $-6^{\circ} \mathrm{C}$ in Apr. Electrolyte leakage increased as temperature decreased from $-15^{\circ} \mathrm{C}$ to $-24^{\circ} \mathrm{C}$ at each assessment time. Sugar gradually decreased after the endodormancy period in the late part of winter, and sugar concentration was overall lower in freezing temperature treatments, while starch increased as a result of changing seasons from Jan. to Apr. The trend of proline concentration was related to the survival rate of peach trees during winter. This study suggests possible safe temperatures for survival and cultivation of peach trees as well as identifying freezing temperature effects on internal components of freeze-injured peach twigs.

\section{Keywords}

Carbohydrate, Survival Rate, EC, Peach Cultivar

\section{Introduction}

Overcoming freezing-temperature stress in fruit trees is a major issue for survival during climate change in tem-

"Corresponding author.

How to cite this paper: Yun, S.K., Bae, H., Chung, K.-H., Yoon, I.K., Nam, E.Y., Kwon, J.H. and Jun, J.H. (2014) Sugar, Starch, and Proline in Peach Trees Exposed to Freezing Temperatures during Dehardening. Agricultural Sciences, 5, 913-921.

http://dx.doi.org/10.4236/as.2014.510099 
perate areas. Global climate change is a main cause of freezing injury in fruit trees under unfavorable conditions because temperature patterns have fluctuated greatly in temperate regions [1]. When trees are exposed to freezing temperature, physical injury is easily incurred, and water movement is commonly restricted. Intracellular ice formation is a severe problem in trees because ice form in xylem parenchyma or between cell walls and protoplast [2], and can be a direct cause of dehydration [3]. Thus endogenous chemical content can be changed in tress injured by freezing. However, it is difficult to measure freezing injury in fruit trees because various fruit tree cultivars respond differently to freezing temperatures. Even different tissues in the same tree, including flower buds, leaf buds, and twigs, have been found to respond differently to freezing temperature [4]. Studies found that internal protein and carbohydrate levels were changed in twig tissue at freezing temperature [5] [6]. Sucrose content in apricot tree increased in January and decreased in March, while starch decreased at freezing temperature in walnut trees during winter [7]. In popular tree, glucose and fructose decreased during dormant periods, and glucose increased with bud burst, while starch content decreased [8]. Proline is considered the main amino acid protecting cells of plants in freezing temperature condition [9].

Peach tree [Prunus persica (L.) Batsch], a major cultivated fruit tree, requires freezing temperature for a certain time to break dormancy. Freezing stress is a dominant environmental problem for peach trees enduring freezing temperature throughout endo-dormancy, bud break, and blooming seasons, because peach trees are very susceptible at freezing temperature to winter mortality. The survival rate of trees during the period of winter to early spring can indicate tolerance of freezing. Electrolyte conductivity is a useful measure of the degree of freezing injury because electrolytes leak from stressed tissue of trees. Several studies included visual observations of tree tissue damaged by freezing injury and measurement of electrolyte conductivity to determine a pattern induced by freezing temperature [10]-[13]. Determining lethal temperatures for survival and biochemical changes provides a key index in confirming cultivar distribution for growing in different locations.

The objectives of this study were to determine temperature at which freezing damages begins, and to evaluate changes in chemical composition of peach twigs in winter and early spring seasons. Little information is currently available about assessing freezing injury in peach trees at certain temperatures in given seasons. In this study, peach trees were observed to determine survival rate, electrolyte leakage, and content of sugar, starch, and proline in order to create an index of injury to be used to properly measure freezing injury in peach trees.

\section{Materials and Methods}

\subsection{Plant Materials and Freezing Treatment}

The experiment was carried out using 7-year-old peach trees grown in the field at the National Institute of Horticultural and Herbal Science, RDA, Suwon, Korea $\left(37^{\circ} 15^{\prime} \mathrm{N}\right.$ and $\left.126^{\circ} 98^{\prime} \mathrm{E}\right)$ in a temperate continental climate (average temp. $12^{\circ} \mathrm{C}$, average precipitation $1312.3 \mathrm{~mm}$ ). Three common peach cultivars "Jinmi", "Changhowonhwangdo", and "Kawanakajima Hakuto" were selected for the study. Although less-cold tolerant cultivars are commonly used for experimental reference, majority of less tolerant cultivars were not survived in the temperate region during the dehardening period. Thus, "Jinmi”, "Changhowonhwangdo", and "Kawanakajima Hakuto" used this study are commonly used as reference cultivars for the medium-cold tolerant cultivars under Korean growing conditions. To determine whether twigs were survival or dead at treated freezing temperature, browning color inside twigs was observed. Samples were collected on Oct. 5, Nov. 5, and Dec. 7 in 2011, and Jan. 15, Feb. 15, Mar. 15, and Apr. 16, 2012. For determination of electrolyte leakage and levels of sugar, starch, and proline, peach twigs were collected on Jan. 15, Feb. 15, Mar. 15, and Apr. 15, 2012 to investigate changes in these metabolites during dehardening (after the endo-dormancy period) in the late winter and the onset of spring conditions. In this study, one-year-old twigs were used, and twigs were collected from 6 twigs from each cultivar. Selected twigs were cut in about $30 \mathrm{~cm}$ length, and the cut twigs were covered with aluminum-foil to avoid direct cold wind and to reduce water loss in a chamber. The covered twigs were immediately placed in environmentally controlled chambers for freezing temperature treatments. The programmed rate of cooling temperature was $-2^{\circ} \mathrm{C}$ per hour down until experimentally designed minimum temperature, and temperature was kept for 12 $\mathrm{h}$ in the chamber. Since the degree of sensitivity of peach trees in natural temperature is different in each month, different temperatures were selected to induce freezing injury. Thus, freezing temperatures in artificially controlled chambers were set up in Oct. $\left(-6^{\circ} \mathrm{C}\right.$ and $\left.-9^{\circ} \mathrm{C}\right)$, Nov. $\left(-6^{\circ} \mathrm{C},-9^{\circ} \mathrm{C}\right.$, and $\left.-12^{\circ} \mathrm{C}\right)$, Dec $\left(-12^{\circ} \mathrm{C},-15^{\circ} \mathrm{C}\right.$, $-18^{\circ} \mathrm{C}$, and $\left.-21^{\circ} \mathrm{C}\right)$, Jan. $\left(-15^{\circ} \mathrm{C},-18^{\circ} \mathrm{C},-21^{\circ} \mathrm{C}\right.$, and $\left.-24^{\circ} \mathrm{C}\right)$, Feb. $\left(-18^{\circ} \mathrm{C},-21^{\circ} \mathrm{C}\right.$, and $\left.-24^{\circ} \mathrm{C}\right)$, Mar. $\left(-12^{\circ} \mathrm{C}\right.$, 
$-15^{\circ} \mathrm{C}$, and $\left.-18^{\circ} \mathrm{C}\right)$, and Apr. $\left(0^{\circ} \mathrm{C},-3^{\circ} \mathrm{C},-6^{\circ} \mathrm{C}\right.$, and $\left.-9^{\circ} \mathrm{C}\right)$. Twigs were exposed in chambers for $12 \mathrm{~h}$ because our preliminary tests showed that freezing injury was not different between $12 \mathrm{~h}$ and $24 \mathrm{~h}$ exposure. All samples were prepared in triplicate.

\subsection{Test of Freezing Injury}

After exposure to freezing temperature for $12 \mathrm{~h}$, twigs were placed at room temperature for 3 days for thawing and then visually inspected. Survival rates (D) of flower buds, leaf buds, and peach twigs was determined by visual inspection. About 12 flower and leaf buds were observed, and 6 twigs in each replication were inspected. Buds and twigs were partially cut and examined for proportion of damaged section $\left(D_{1}\right)$ over total number (about 12 - 15) of the cut parts $\left(\mathrm{D}_{2}\right)$. Damaged tissue was identified by tissue browning. Visual assessment of browning was expressed as percentage, calculated as $\mathrm{D} \%=\mathrm{D}_{1} / \mathrm{D}_{2} \times 100$. Whether the browning color judgment or not was applied to individual cut part.

Electrolyte leakage (EL) was measured to detect the degree of freezing injury. Twigs from each freezing treatment (6 twigs from each of 3 or 5 trees) were cut into $1 \mathrm{~cm}$ pieces, and 5 pieces were soaked in $10 \mathrm{~mL}$ of distilled water in test tubes. The tubes were incubated at $20^{\circ} \mathrm{C}$ for $12 \mathrm{~h}$ and measured $\left(\mathrm{EL}_{1}\right)$. Then tubes were sealed, and boiled at $100^{\circ} \mathrm{C}$ for $30 \mathrm{~min}$ in the water bath and measured again $\left(\mathrm{EL}_{2}\right)$. Electrolyte leakage was calculated, and expressed as percentage, with $\mathrm{EL} \%=\mathrm{EL}_{1} / \mathrm{EL}_{2} \times 100$.

\subsection{Determination of Sugar and Starch}

The concentration of sugar and starch in twigs were determined to compare differences between those grown under field condition in natural temperate climate and those stored at artificially controlled freezing temperature. Trees were grown as peach seedling rootstock, and trained to Y-shape with a spacing of $4 \times 5 \mathrm{~m}$ of a 7-year-old tree. Selected twigs were treated in the same condition with twigs for the test of freezing injury. For comparison of sugar and starch in controlled (chamber) freeze twigs and field twigs, a freezing temperature threshold for peach survival was selected for each month. Since the treated temperatures at $-21^{\circ} \mathrm{C}$ in Jan. and Feb., $-18^{\circ} \mathrm{C}$ in Mar., and $-6^{\circ} \mathrm{C}$ in Apr. in the chamber for $12 \mathrm{~h}$ were the least temperature for tree survival, the marginal temperature was selected for experiment. The twigs were freeze-dried and finely ground for analysis. For the sugar analysis, $0.1 \mathrm{~g}$ of ground sample was mixed with $10 \mathrm{~mL}$ of $80 \%$ ethanol. The mixture was extracted using sonication for $60 \mathrm{~min}$. The extract was evaporated under vacuum until dry. About $1 \mathrm{~mL}$ of distilled water was dissolved, and the extract was filtrated in a $0.45 \mu \mathrm{m}$ micron filter. Soluble sugar was quantified by HPLC with a reflective index detector. Sugar-Pak ${ }^{\mathrm{TM}} 1$ column $\left(6.5 \times 300 \mathrm{~mm}\right.$, Waters, USA) was used at $90^{\circ} \mathrm{C}$ with a flow rate of $0.5 \mathrm{~mL} \cdot \mathrm{min}^{-1}$, and the mobile phase was ultrapure water.

Total starch was determined using a total starch analysis kit (Megazyme International Ireland Ltd., Wicklow, Ireland) with modification. A milled sample $(0.1 \mathrm{~g})$ was homogenized with $0.2 \mathrm{~mL}$ of $80 \%$ ethanol, and a mixed solution ( $3 \mathrm{~mL}$ ) of $\alpha$-amylase and $100 \mathrm{mM}$ sodium acetate $(1: 30, \mathrm{v} / \mathrm{v})$ was added in homogenate. The mixture was incubated at $100^{\circ} \mathrm{C}$ for $12 \mathrm{~min}$. During boiling, the mixture was vigorously stirred, and then $0.1 \mathrm{~mL}$ of amyloglucosidase was added to the mixture. The second incubation was processed at $50^{\circ} \mathrm{C}$ for $30 \mathrm{~min}$, and water was added to the mixture up to $10 \mathrm{~mL}$. After centrifugation, $0.1 \mathrm{~mL}$ of supernatant was mixed with $3 \mathrm{ml}$ of glucose oxidase-peroxidase (GOPOD) reagent. A third incubation was completed at $50^{\circ} \mathrm{C}$ for $20 \mathrm{~min}$, and the mixture was cooled down. Starch was spectrophotometrically measured at $510 \mathrm{~nm}$ for each sample, along with a D-glucose control against the reagent blank.

\subsection{Proline Analysis}

Proline content was determined using a modified method of Bates [14]. For comparison of proline concentration, temperature treatments were applied as described in section 2.3. The concentration of proline was compared between field and artificially controlled freezing temperature treatments. Proline (1 g) standard was dissolved in distilled water, and prepared at different concentrations $\left(0,20,40,60,80,100,200\right.$, and $\left.300 \mu \mathrm{g} \cdot \mathrm{g}^{-1}\right)$ using $3 \%$ sulfosalicylic acid. A milled twig sample $(0.3 \mathrm{~g})$ was mixed with $10 \mathrm{~mL}$ of $3 \%$ sulfosalicylic acid. After incubation for 30 min using sonication, the extraction was centrifuged for $15 \mathrm{~min}$. The extract $(2 \mathrm{~mL})$ was mixed with $1.5 \mathrm{~mL}$ of acid ninhydrin solution and $1.5 \mathrm{~mL}$ of acetic acid, and the mixture was then incubated at $100^{\circ} \mathrm{C}$ for 45 min. After it had cooled down, toluene ( $3 \mathrm{~mL}$ ) was mixed in and the absorbance was read at $520 \mathrm{~nm}$. 


\subsection{Statistical Analysis}

The data were analyzed using SAS 9.2 (SAS Institute, Cary, NC, USA), and group means were compared for significant differences at 5\% level with Tukey's test. The data were presented as average and standard error.

\section{Results and Discussion}

\subsection{Visual Assessment at Freezing Temperature}

When twigs are kept under freezing conditions, the symptom of freezing injury can easily be observed. Brownish color is the most common sign of damaged buds and twigs (Figure 1). Freezing injury is variable in tissue of buds and twigs exposed to freezing temperatures in the different seasons (Table 1). In this study, the rate of tissue browning was examined primarily on the twigs because the survival rate of twigs was more stable and associated with higher rate of survival in trees than that of flower and leaf buds, although survival of flower buds is related to fruit yields. A higher browning rate was associated with lower survival rate at freezing temperature. In October, browning rate was more than $80 \%$ in "Jinmi”, "Changhowonhwangdo", and "Kawanakajima Hakuto" at $-9^{\circ} \mathrm{C}$. Twigs tissue started dying out at $-9^{\circ} \mathrm{C}$ in November, $-15^{\circ} \mathrm{C}$ in December, $-21^{\circ} \mathrm{C}$ in January and February. However, most twigs of "Changhowonhwangdo", and "Kawanakajima Hakuto" showed damage at $-18^{\circ} \mathrm{C}$ in March. The lowest temperature observed at which twigs survived was $-6^{\circ} \mathrm{C}$ in April. A dormant season lasted from October to early March, with a deep dormant period from December through February. When trees were in the middle of deep dormancy, they were more tolerant of lower temperatures from December $\left(-18^{\circ} \mathrm{C}\right)$ to February $\left(-21^{\circ} \mathrm{C}\right)$ than in other seasons. The results indicated that it is important to be aware of the lowest temperature at which tree can be damaged in different seasons.

\subsection{Electrolyte Leakage}

To examine the relationship between the rate of electrolyte leakage and decreasing temperature, percentage of electrolyte leakage was measured from January to April in three peach cultivars (Figure 2). Increase in electrolyte leakage is generally considered an indicator of freezing injury in twigs. Electrolyte leakage showed little increase $(\leq 25 \%)$ as temperatures decreased from January to March, and no distinct variation was observed among peach cultivars. In April, electrolyte leakage noticeably increased (30\% - 55\%) compared with other seasons, and significant differences were detected among peach cultivars. The reason could be that peach trees in bloom in April are more susceptible to freezing temperatures than they are during the dormant periods from January to March. In a comparison of cultivars, the rate of electrolyte leakage was higher in "Jinmi" than in "Changhowonhwangdo" and "Kawanakajima Hakuto". The result was consistent with browning observed at $-6^{\circ} \mathrm{C}$ in April (Table 1), and indicated that temperature, during critical periods of dormancy, bud burst, and bloom, is more important for observations of effects of freezing conditions on trees than absolute freezing temperatures.

\subsection{Seasonal Changes in Sugar and Starch}

The content of soluble sugar at different rates of freezing injury in peach twigs was variable during the season from January to April. Soluble sugar from three peach cultivars showed different seasonal content, while the seasonal patterns of sugar content in peach trees were similar between field and freezing temperature conditions

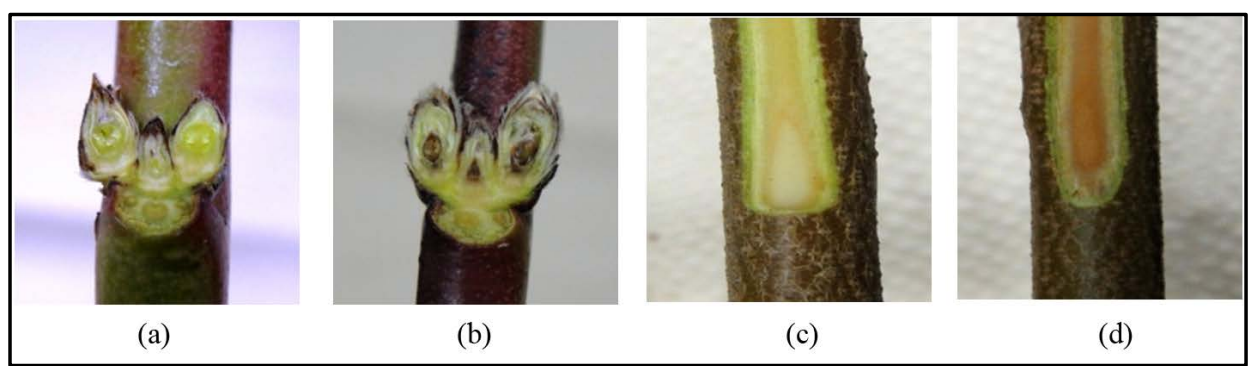

Figure 1. Visual observation of tissue browning in flower buds, leaf buds, and twigs of peach cultivars exposed to freezing temperature. (a), normal flower and leaf buds; (b), freezing injury of flower and leaf buds; (c), normal twigs; (d), freezing injury of twigs. 
Table 1. The browning rate ${ }^{\mathrm{z}}$ of flower buds, leaf buds, and twigs of peach cultivars.

\begin{tabular}{|c|c|c|c|c|c|c|c|c|c|c|}
\hline & Treated & & Flower bud $(9$ & & & Leaf bud (\%) & & & Twig (\%) & \\
\hline Date & Temp. & $\mathrm{JM}^{\mathrm{y}}$ & $\mathrm{CH}$ & $\mathrm{KH}$ & $\mathrm{JM}$ & $\mathrm{CH}$ & $\mathrm{KH}$ & $\mathrm{JM}$ & $\mathrm{CH}$ & $\mathrm{KH}$ \\
\hline \multirow{3}{*}{$\begin{array}{c}\text { October } \\
11\end{array}$} & $-6^{\circ} \mathrm{C}$ & $23.5 \pm 5.6 a$ & $26.7 \pm 12.0 \mathrm{a}$ & $20.4 \pm 11.6 b$ & $22.1 \pm 6.0 \mathrm{a}$ & $21.6 \pm 11.1 \mathrm{a}$ & $29.6 \pm 5.5 a$ & $83.4 \pm 9.5 a$ & $44.4 \pm 24.2 \mathrm{a}$ & $66.7 \pm 16.7 \mathrm{a}$ \\
\hline & $-9^{\circ} \mathrm{C}$ & $7.0 \pm 4.4 \mathrm{a}$ & $47.8 \pm 24.8 a$ & $81.0 \pm 15.6 a$ & $26.0 \pm 3.2 \mathrm{a}$ & $42.8 \pm 21.4 a$ & $53.8 \pm 17.7 a$ & $89.0 \pm 11.0 \mathrm{a}$ & $88.9 \pm 5.6 a$ & $88.9 \pm 11.1 \mathrm{a}$ \\
\hline & $-6^{\circ} \mathrm{C}$ & $8.3 \pm 5.2 \mathrm{a}$ & $26.3 \pm 6.9 a$ & $3.3 \pm 3.3 b$ & 0 & $11.6 \pm 8.7 \mathrm{a}$ & $6.1 \pm 6.1 b$ & 0 & 0 & 0 \\
\hline \multirow{3}{*}{$\begin{array}{c}\text { November } \\
11\end{array}$} & $-9^{\circ} \mathrm{C}$ & $9.3 \pm 0.7 a$ & $18.3 \pm 2.4 a$ & $27.4 \pm 1.2 \mathrm{a}$ & $10.0 \pm 5.8 a$ & $17.7 \pm 13.0 \mathrm{a}$ & $44.4 \pm 8.0 \mathrm{a}$ & $61.0 \pm 20.1 \mathrm{a}$ & $50.0 \pm 0 b$ & $72.2 \pm 14.7 \mathrm{a}$ \\
\hline & $-12^{\circ} \mathrm{C}$ & $12.7 \pm 6.6 \mathrm{a}$ & $24.2 \pm 5.5 a$ & $39.4 \pm 4.6 \mathrm{a}$ & $13.3 \pm 3.4 \mathrm{a}$ & $42.4 \pm 10.5 a$ & $33.3 \pm 8.3 \mathrm{ab}$ & $55.7 \pm 5.7 \mathrm{ab}$ & $100.0 \pm 0 \mathrm{a}$ & $100.0 \pm 0 \mathrm{a}$ \\
\hline & $-12^{\circ} \mathrm{C}$ & $17.4 \pm 8.1 b$ & $30.0 \pm 15.3 b$ & $26.7 \pm 7.0 \mathrm{~b}$ & 0 & $31.3 \pm 17.8 b$ & $36.0 \pm 7.4 \mathrm{~b}$ & $11.1 \pm 5.6 b$ & $44.3 \pm 5.7 b$ & $44.3 \pm 5.7 b$ \\
\hline \multirow{4}{*}{$\begin{array}{c}\text { December } \\
11\end{array}$} & $-15^{\circ} \mathrm{C}$ & $25.0 \pm 2.6 b$ & $10.0 \pm 10.0 \mathrm{~b}$ & $75.0 \pm 25 a b$ & 0 & $30.0 \pm 6.8 b$ & $24.3 \pm 12.3 b$ & $22.2 \pm 5.6 b$ & $50.0 \pm 0 b$ & $55.7 \pm 5.7 b$ \\
\hline & $-18^{\circ} \mathrm{C}$ & $100.0 \pm 0 \mathrm{a}$ & $100.0 \pm 0 \mathrm{a}$ & $100.0 \pm 0 \mathrm{a}$ & $100.0 \pm 0 \mathrm{a}$ & $93.3 \pm 11.1 \mathrm{a}$ & $100.0 \pm 0 \mathrm{a}$ & $100.0 \pm 0 \mathrm{a}$ & $100.0 \pm 0 \mathrm{a}$ & $100.0 \pm 0 \mathrm{a}$ \\
\hline & $-21^{\circ} \mathrm{C}$ & $100.0 \pm 0 \mathrm{a}$ & $100.0 \pm 0 \mathrm{a}$ & $100.0 \pm 0 \mathrm{a}$ & $100.0 \pm 0 \mathrm{a}$ & $93.3 \pm 21.4 \mathrm{a}$ & $100.0 \pm 0 \mathrm{a}$ & $100.0 \pm 0 \mathrm{a}$ & $100.0 \pm 0 \mathrm{a}$ & $100.0 \pm 0 \mathrm{a}$ \\
\hline & $-15^{\circ} \mathrm{C}$ & $4.1 \pm 1.5 b$ & $12.5 \pm 6.6 b$ & 0 & 0 & 0 & 0 & 0 & 0 & 0 \\
\hline \multirow{4}{*}{$\begin{array}{c}\text { January } \\
12\end{array}$} & $-18^{\circ} \mathrm{C}$ & $4.9 \pm 2.8 b$ & $1.8 \pm 1.8 \mathrm{~b}$ & $5.8 \pm 3.6 b$ & $6.4 \pm 3.2 \mathrm{~b}$ & 0 & 0 & 0 & 0 & 0 \\
\hline & $-21^{\circ} \mathrm{C}$ & $95.8 \pm 2.1 \mathrm{a}$ & $100.0 \pm 0 \mathrm{a}$ & $100.0 \pm 0 \mathrm{a}$ & $100.0 \pm 0 \mathrm{a}$ & $100.0 \pm 11.1 \mathrm{a}$ & $100.0 \pm 0 \mathrm{a}$ & $44.4 \pm 5.6 b$ & $72.2 \pm 14.7 \mathrm{a}$ & $66.7 \pm 16.7 \mathrm{a}$ \\
\hline & $-24^{\circ} \mathrm{C}$ & $100.0 \pm 0 \mathrm{a}$ & $100.0 \pm 0 \mathrm{a}$ & $100.0 \pm 0 \mathrm{a}$ & $100.0 \pm 0 \mathrm{a}$ & $100.0 \pm 21.4 \mathrm{a}$ & $100.0 \pm 0 \mathrm{a}$ & $100.0 \pm 0 \mathrm{a}$ & $100.0 \pm 0 \mathrm{a}$ & $72.2 \pm 11.1 \mathrm{a}$ \\
\hline & $-18^{\circ} \mathrm{C}$ & $1.8 \pm 1.8 \mathrm{c}$ & 0 & $5.8 \pm 3.1 b$ & 0 & 0 & $10.3 \pm 1.2 \mathrm{c}$ & 0 & 0 & 0 \\
\hline \multirow{3}{*}{$\begin{array}{c}\text { February } \\
12\end{array}$} & $-21^{\circ} \mathrm{C}$ & $58.7 \pm 8.0 \mathrm{~b}$ & $49.1 \pm 6.4 b$ & $33.9 \pm 19.3 b$ & $50.8 \pm 6.5 b$ & $49.1 \pm 4.0 \mathrm{~b}$ & $43.6 \pm 6.1 b$ & $33.3 \pm 0 b$ & $72.2 \pm 5.6 b$ & $55.6 \pm 5.6 b$ \\
\hline & $-24^{\circ} \mathrm{C}$ & $100.0 \pm 0 \mathrm{a}$ & $100.0 \pm 0 \mathrm{a}$ & $100.0 \pm 0 \mathrm{a}$ & $100.0 \pm 0 \mathrm{a}$ & $100.0 \pm 0 \mathrm{a}$ & $100.0 \pm 0 \mathrm{a}$ & $100.0 \pm 0 \mathrm{a}$ & $100.0 \pm 0 \mathrm{a}$ & $100.0 \pm 0 \mathrm{a}$ \\
\hline & $-12^{\circ} \mathrm{C}$ & 0 & 0 & 0 & 0 & 0 & 0 & 0 & 0 & 0 \\
\hline \multirow{3}{*}{$\begin{array}{l}\text { March } \\
12\end{array}$} & $-15^{\circ} \mathrm{C}$ & $17.3 \pm 10.2 b$ & $17.5 \pm 1.3 \mathrm{~b}$ & $6.4 \pm 3.9 b$ & 0 & 0 & 0 & 0 & 0 & 0 \\
\hline & $-18^{\circ} \mathrm{C}$ & $100.0 \pm 0 \mathrm{a}$ & $100.0 \pm 0 \mathrm{a}$ & $100.0 \pm 0 \mathrm{a}$ & $100.0 \pm 0 \mathrm{a}$ & $100.0 \pm 0 \mathrm{a}$ & $100.0 \pm 0 \mathrm{a}$ & $38.9 \pm 5.6 \mathrm{a}$ & $100.0 \pm 0 \mathrm{a}$ & $88.9 \pm 11.1 \mathrm{a}$ \\
\hline & 0 & 0 & 0 & 0 & 0 & 0 & 0 & 0 & 0 & 0 \\
\hline \multirow{3}{*}{$\begin{array}{c}\text { April } \\
12\end{array}$} & $-3^{\circ} \mathrm{C}$ & 0 & 0 & 0 & 0 & 0 & 0 & 0 & 0 & 0 \\
\hline & $-6^{\circ} \mathrm{C}$ & $83.2 \pm 1.6 a$ & $81.4 \pm 6.2 b$ & $59.3 \pm 20.6 a$ & $100.0 \pm 0 \mathrm{a}$ & $100.0 \pm 0 a$ & $66.4 \pm 2.2 \mathrm{a}$ & $55.6 \pm 5.6 \mathrm{a}$ & $50.0 \pm 9.6 \mathrm{~b}$ & $38.9 \pm 5.6 a$ \\
\hline & $-9^{\circ} \mathrm{C}$ & $75.1 \pm 7.4 a$ & $100.0 \pm 0 \mathrm{a}$ & $34.4 \pm 8.7 \mathrm{ab}$ & $95.2 \pm 4.8 \mathrm{a}$ & $100.0 \pm 0 \mathrm{a}$ & $39.9 \pm 9.4 b$ & $77.8 \pm 8.7 \mathrm{a}$ & $88.9 \pm 11.1 \mathrm{a}$ & $38.9 \pm 5.6 a$ \\
\hline
\end{tabular}

${ }^{\mathrm{z}}$ Mean \pm Standard error, Means in the same column followed by the same letter are not significantly different at $P \geq 0.05$, according to Tukey's test. ${ }^{\mathrm{y} J M}$ : Jinmi, CH: Changhowonhwangdo, KH: Kawanakajima Hakuto.

(Figure 3). In a comparison of field and freezing temperature treatments, peach trees exposed to freezing temperature had lower sugar content than those in the field, although sugar content is commonly expected to increase in a freezing temperature condition. The finding could be explained by the fact that freezing temperature treatment in this study was the lowest survival temperature, and thus sugar content in field conditions would obviously be higher than in the freezing temperature treatments. Soluble sugar content is related to an index of cold-tolerance, and sugar content increased in January and February, and decreased at time of bud break in March. Sugar accumulation then increased during bud burst and blooming in April. The trend in sugar content could be attributed to sucrose content in peach twigs. As the major sugar in tree, sucrose decreased toward the end of winter, while glucose and fructose increased in this study (data not shown). Sucrose is considered as an energy source for normal growth of trees. Sugar content was high during the dormant period in January and February, and then decreased until March. A previous study showed that sugar increased in December and gradually dropped from February to April in peach trees [15]. With buds breaking and bursting in late March, sugar content increased. The results indicated that an increase in glucose and fructose prior to bud break was associated with a decrease in sucrose and starch.

Content of starch in the twigs of peach tree cultivars "Jinmi", "Changhowonhwangdo", and "Kawanakajima Hakuto" was observed in seasonal variation from January to April (Figure 3). Starch was the dominant storage 

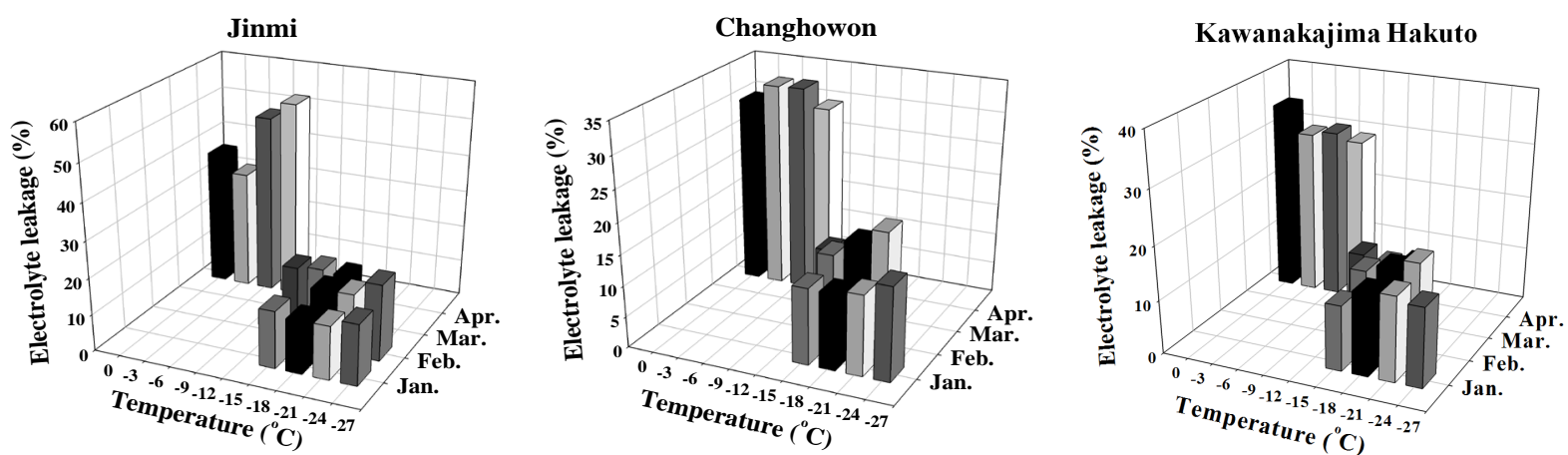

Figure 2. Electrolyte leakage (\%) from the twigs of "Jinmi”, “Changhowonhwangdo”, and "KawanakajimaHakuto” exposed at different range of freezing temperature in January, February, March, and April.

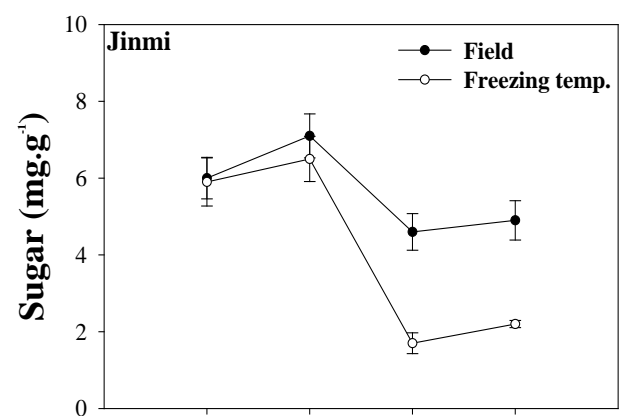

Jan. Feb. Mar. Apr.

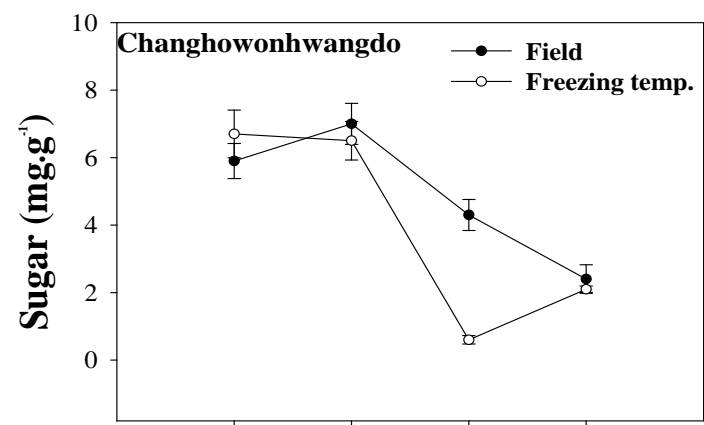

Jan. Feb. Mar. Apr.

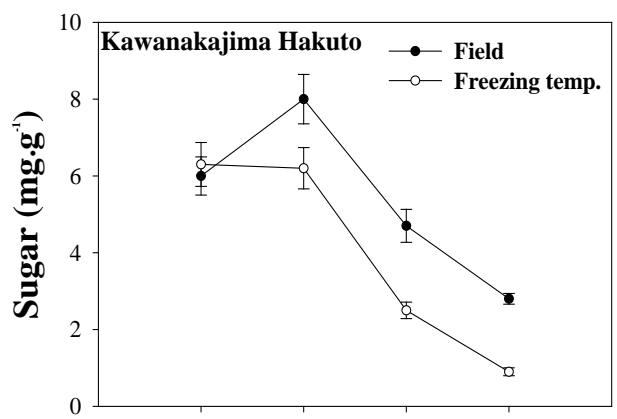

Jan. Feb. Mar. Apr.

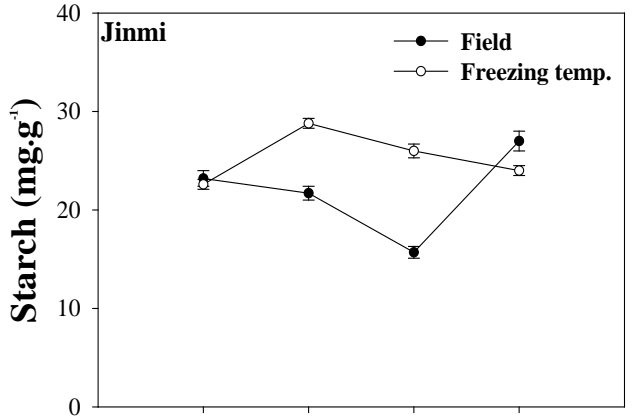

Jan. Feb. Mar. Apr.

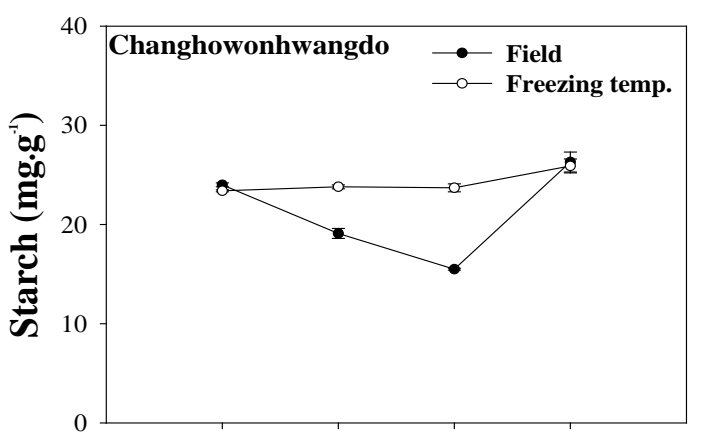

Jan. Feb. Mar. Apr.

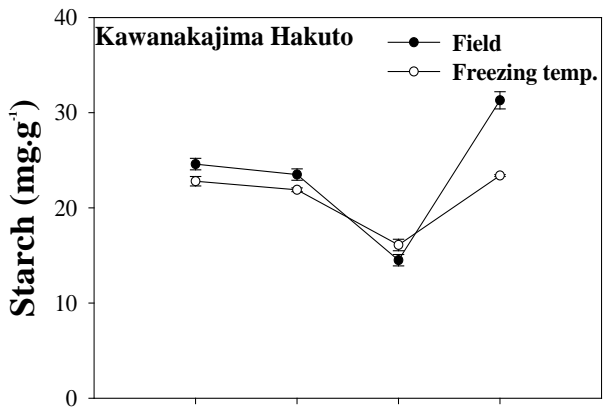

Jan. Feb. Mar. Apr.

Figure 3. Seasonal changes in sugar and starch content $\left(\mathrm{mg} \cdot \mathrm{g}^{-1}\right)$ in the twigs of "Jinmi”, "Changhowonhwangdo", and "Kawanakajima Hakuto" peach grown in the field and subjected to freezing temperatures in January $\left(21^{\circ} \mathrm{C}\right)$, February $\left(21^{\circ} \mathrm{C}\right)$, March $\left(-18^{\circ} \mathrm{C}\right)$, and April $\left(-6^{\circ} \mathrm{C}\right)$. 
carbohydrate and in much greater concentration in freezing temperature treatments compared with field conditions, except in "Kawanakajima Hakuto". As with sugar content, starch was at its lowest content during bud break in March, and then increased in April, going into spring. The low level of starch in field condition was due to the much faster use of starch in normal growth of field trees than in freezing temperatures. A recent report showed starch content of oak and beech trees decreasing from December to February, and then increasing from March to May [16]. Another study found that starch decreased in pear trees from January to March as sugars increased as a result of starch degradation [17]. In our result, the transition from decreasing starch to increasing sugar was not clear at time of bud burst. It could possibly be explained by the fact that the transition from starch to sugar can be observed more in buds than in twigs of trees.

\subsection{Proline Content}

Proline in plants commonly increased at freezing temperature and with unfavorable environmental stress [18]-[20]. As shown in Figure 4, total proline content in three peach twigs was similar in field and freezing
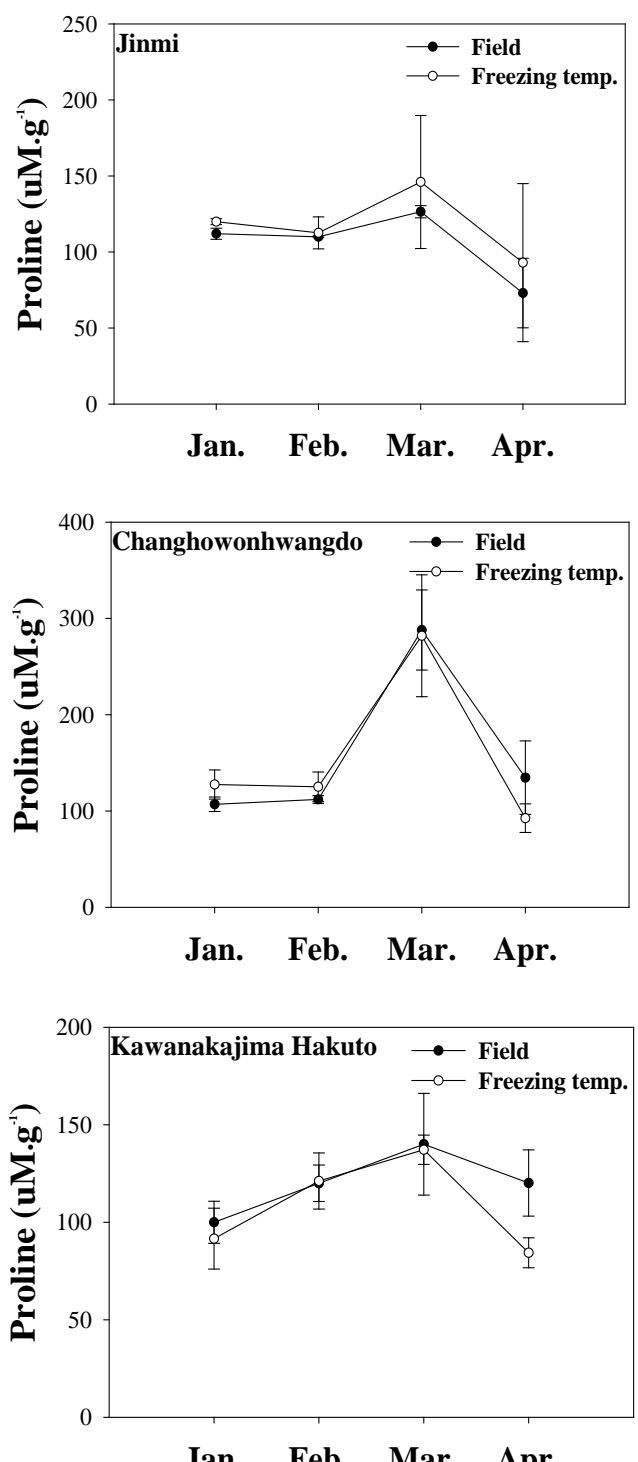

Figure 4. Proline content of "Jinmi”, "Changhowonhwangdo", and "Kawanakajima Hakuto" peach cultivars grown in the field and subjected to freezing temperatures in January $\left(21^{\circ} \mathrm{C}\right)$, February $\left(21^{\circ} \mathrm{C}\right)$, March $\left(-18^{\circ} \mathrm{C}\right)$, and April $\left(-6^{\circ} \mathrm{C}\right)$. 
temperature treatment in January, February, and April, while proline content was significantly higher in March than in January, February, and April. It could be that trees are more vulnerable at freezing temperature at time of bud break in March, and thus proline, an amino acid, could be at higher content than in other seasons. Studies found a positive relationship between proline content and sugar accumulation [21]-[23], while our study showed no consistent results for proline and sugar content at different temperatures as the seasons changed. Proline accumulation was likely associated with rate of freezing injury response in different seasons.

\section{Conclusion}

Peach trees were susceptible to unfavorable freezing temperature. The results found freezing injury to be fatal below a certain temperature, and variable patterns were seen in internal chemical components during seasonal changes. Since the three peach cultivars showed similar medium-cold tolerance, their internal components were not significantly different in different seasons. This study demonstrated that freezing temperatures at which damage begins in trees were $-21^{\circ} \mathrm{C}$ during a deep dormant period from January to early February, $-18^{\circ} \mathrm{C}$ during the period innate dormancy was broken and imposed dormancy began, from late February to March, and $-6^{\circ} \mathrm{C}$ during the period of blooming in mid-April, along with different content of endogenous components.

\section{References}

[1] Pagter, M., Hausman, J.F. and Arora, R. (2011) Deacclimation Kinetics and Carbohydrate Changes in Stem Tissues of Hydrangea in Response to an Experimental Warm Spell. Plant Science, 180, 140-148.

http://dx.doi.org/10.1016/j.plantsci.2010.07.009

[2] Pearce, R.S. (2001) Plant Freezing and Damage. Annals of Botany, 87, 417-424. http://dx.doi.org/10.1006/anbo.2000.1352

[3] Yadav, S.K. (2010) Cold Stress Tolerance Mechanisms in Plants. A Review. Agronomy for Sustainable Development, 30, 515-527. http://dx.doi.org/10.1051/agro/2009050

[4] Palonen, P. and Buszard, D. (1997) Current State of Cold Hardiness Research on Fruit Crops. Canadian Journal of Plant Science, 77, 399-420. http://dx.doi.org/10.4141/P96-013

[5] Renaut, J., Hausman, J.F., Bassett, C., Artlip, T., Cauchie, H.M., Witters, E. and Wisniewski, M. (2008) Quantitative Proteomic Analysis of Short Photoperiod and Low-Temperature Responses in Bark Tissues of Peach (Prunus persica L. Batsch). Tree Genetics \& Genomes, 4, 589-600. http://dx.doi.org/10.1007/s11295-008-0134-4

[6] Bassett, C.L., Wisniewski, M.E., Artlip, T.S., Norelli, J.L., Renaut, J. and Farrell, R.E. (2006) Global Analysis of Genes Regulated by Low Temperature and Photoperiod in Peach Bark. Journal of the American Society for Horticultural Science, 131, 551-563.

[7] Améglio, T., Decourteix, M., Alves, G., Valentin, V., Sakr, S., Julien, J.L., Petel, G., Guilliot, A. and Lacointe, A. (2004) Temperature Effects on Xylem Sap Osmolarity in Walnut Trees: Evidence for a Vitalistic Model of Winter Embolism Repair. Tree Physiology, 24, 785-793. http://dx.doi.org/10.1093/treephys/24.7.785

[8] Regier, N., Streb, S., Zeeman, S.C. and Frey, B. (2010) Seasonal Changes in Starch and Sugar Content of Poplar (Populus deltoides $\times$ nigra cv. Dorskamp) and the Impact of Stem Girdling on Carbohydrate Allocation to Roots. Tree Physiology, 30, 979-987. http://dx.doi.org/10.1093/treephys/tpq047

[9] Zhao, D.Y., Shen, L., Fan, B., Liu, K.L., Yu, M.M., Zheng, Y., Ding, Y. and Sheng, J.P. (2009) Physiological and Genetic Properties of Tomato Fruits from 2 Cultivars Differing in Chilling Tolerance at Cold Storage. Journal of Food Science, 74, C348-C352. http://dx.doi.org/10.1111/j.1750-3841.2009.01156.X

[10] Davarynejad, G.H., Aryanpooya, Z. and Attar, S.H. (2012) Frost Injury in Buds and Wood of Several Peach and Nectarine Cultivars. Acta Horticulturae, 962, 217-224.

[11] Azzarello, E., Mugnai, S., Pandolfi, C., Masi, E., Marone, E. and Mancuso, S. (2009) Comparing Image (Fractal Analysis) and Electrochemical (Impedance Spectroscopy and Electrolyte Leakage) Techniques for the Assessment of the Freezing Tolerance in Olive. Trees, 23, 159-167. http://dx.doi.org/10.1007/s00468-008-0264-1

[12] Prášil, I. and Zámečnik, J. (1998) The Use of a Conductivity Measurement Method for Assessing Freezing Injury: I. Influence of Leakage Time, Segment Number, Size and Shape in a Sample on Evaluation of the Degree of Injury. Environmental and Experimental Botany, 40, 1-10. http://dx.doi.org/10.1016/S0098-8472(98)00010-0

[13] Mancuso, S., Nicese, F.P., Masi, E. and Azzarello, E. (2004) Comparing Fractal Analysis, Electrical Impedance and Electrolyte Leakage for the Assessment of Cold Tolerance in Callistemon and Grevillea spp. Journal of Horticultural Science and Biotechnology, 79, 627-632.

[14] Bates, L.S., Waldren, R.P. and Teare, I.D. (1973) Rapid Determination of Free Proline for Water-Stress Studies. Plant 
and Soil, 39, 205-207. http://dx.doi.org/10.1007/BF00018060

[15] Yooyongwech, S., Sugaya, S., Sekozawa, Y. and Gemma, H. (2009) Differential Adaptation of High- and Low-Chill Dormant Peaches in Winter through Aquaporin Gene Expression and Soluble Sugar Content. Plant Cell Reports, 28, 1709-1715. http://dx.doi.org/10.1007/s00299-009-0770-7

[16] El-Zein, R., Maillard, P., Bréda, N., Marchand, J., Montpied, P. and Gérant, D. (2011) Seasonal Changes of C and N Non-Structural Compounds in the Stem Sapwood of Adult Sessile Oak and Beech Trees. Tree Physiology, 31, 843-854. http://dx.doi.org/10.1093/treephys/tpr074

[17] Ito, A., Sakamoto, D. and Moriguchi, T. (2012) Carbohydrate Metabolism and Its Possible Roles in Endodormancy Transition in Japanese Pear. Scientia Horticulturae, 144, 187-194. http://dx.doi.org/10.1016/j.scienta.2012.07.009

[18] Ashraf, M. and Foolad, M.R. (2007) Roles of Glycine Betaine and Proline in Improving Plant Abiotic Stress Resistance. Environmental and Experimental Botany, 59, 206-216. http://dx.doi.org/10.1016/j.envexpbot.2005.12.006

[19] Ahmed, C.B., Rouina, B.B., Sensoy, S., Boukhriss, M. and Abdullah, F.B. (2010) Exogenous Proline Effects on Photosynthetic performance and Antioxidant Defense System of Young Olive Tree. Journal of Agricultural and Food Chemistry, 58, 4216-4222. http://dx.doi.org/10.1021/jf9041479

[20] Sarkar, D., Bhowmik, P.C., Kwon, Y.I. and Shetty, K. (2009) Cold Acclimation Responses of Three Cool-Season Turfgrasses and the Role of Proline-Associated Pentose Phosphate Pathway. Journal of the American Society for Horticultural Science, 134, 210-220.

[21] Asfi, M., Ouzounidou, G., Panajiotidis, S., Therios, I. and Moustakas, M. (2012) Toxicity Effects of Olive-Mill Wastewater on Growth, Photosynthesis and Pollen Morphology of Spinach Plants. Ecotoxicology and Environmental Safety, 80, 69-75. http://dx.doi.org/10.1016/j.ecoenv.2012.02.030

[22] Cataldi, T.R.I. and Nardiello, D. (2003) Determination of Free Proline and Monosaccharides in Wine Samples by High-Performance Anion-Exchange Chromatography with Pulsed Amperometric Detection (HPAEC-PAD). Journal of Agricultural and Food Chemistry, 51, 3737-3742. http://dx.doi.org/10.1021/jf034069c

[23] Laura, M., Consonni, R., Locatelli, F., Fumagalli, E., Allavena, A., Coraggio, I. and Mattana, M. (2010) Metabolic Response to Cold and Freezing of Osteospermum ecklonis Overexpressing Osmyb4. Plant Physiology and Biochemistry, 48, 764-771. http://dx.doi.org/10.1016/j.plaphy.2010.06.003 
Scientific Research Publishing (SCIRP) is one of the largest Open Access journal publishers. It is currently publishing more than 200 open access, online, peer-reviewed journals covering a wide range of academic disciplines. SCIRP serves the worldwide academic communities and contributes to the progress and application of science with its publication.

Other selected journals from SCIRP are listed as below. Submit your manuscript to us via either submit@scirp.org or Online Submission Portal.
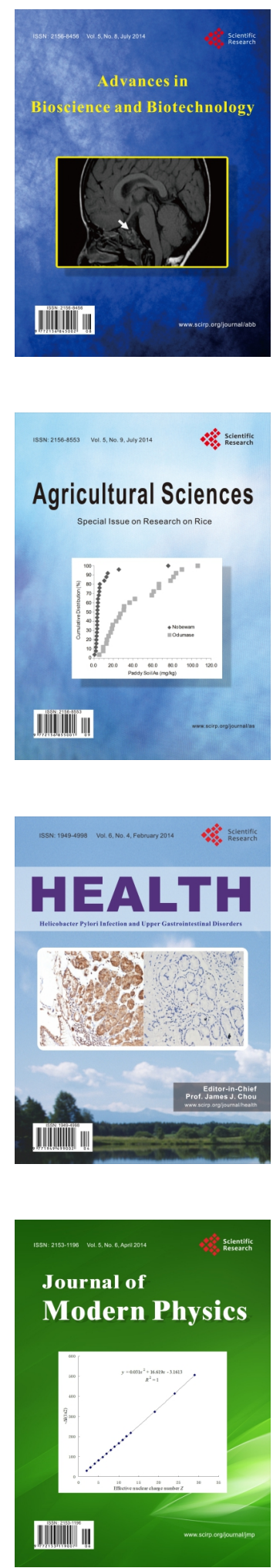
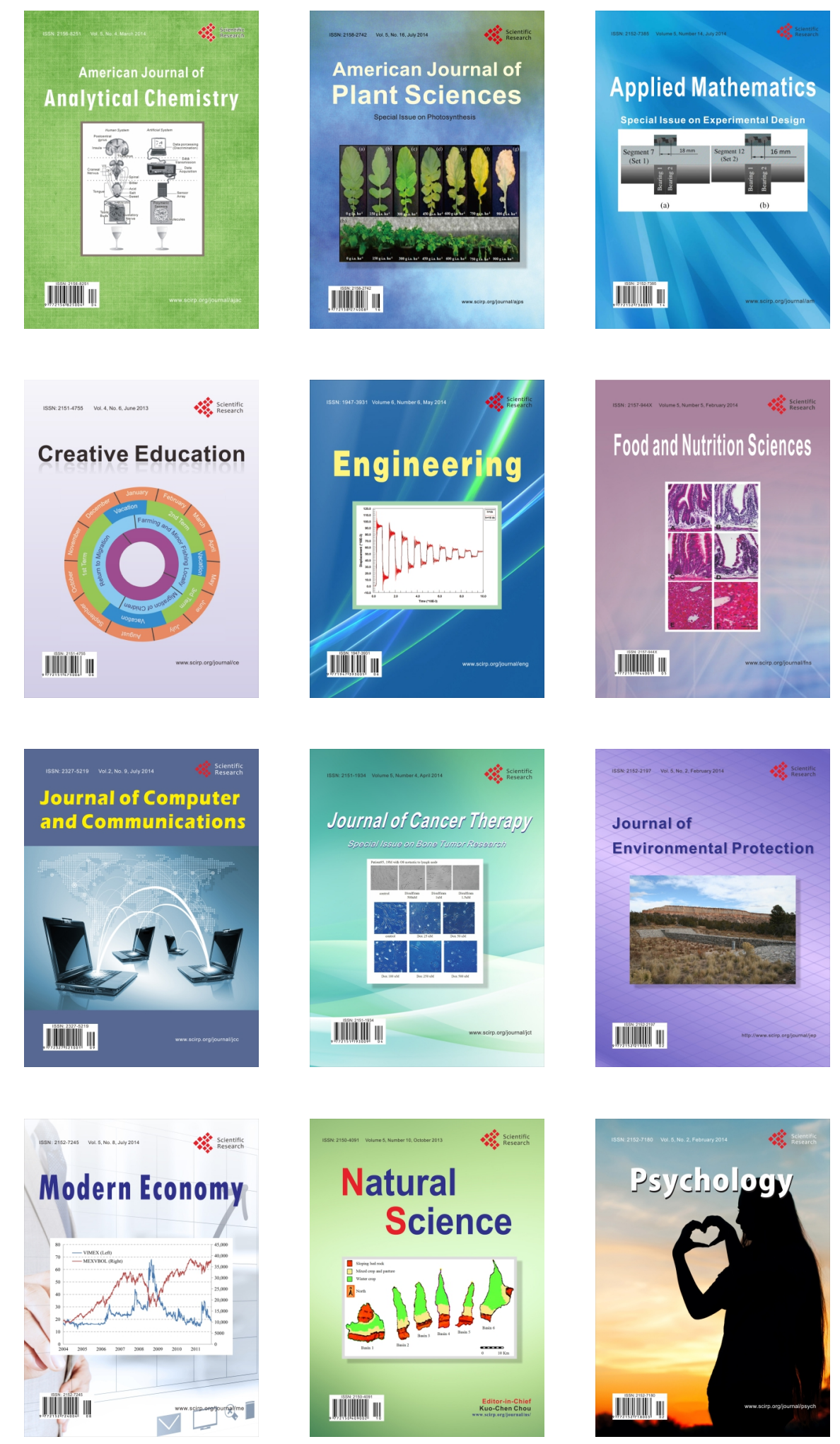